\title{
The sociogenesis of terrorism as part of English-Irish relations during the nineteenth century
}

\author{
Michael Dunning \\ Volume 6, Issue 1, May 2017 \\ Permalink: http://hdl.handle.net/2027/spo.11217607.0006.103 [http://hdl.handle.net/2027/spo.11217607.0006.103]
}

(oc) EY-NC-ND [http://creativecommons.org/licenses/by-nc-nd/3.0/]

\begin{abstract}
In this paper, I examine the 'sociogenesis' of terrorism in the context of established-outsider figurations involving the English and Irish Catholics during the nineteenth century. I do this through an analysis of newspaper reports over the course of that period. I locate this within a wider framework of research on terrorism that has tended to essentialise the concept of terrorism, while at the same time reproduce 'established' group narratives of the phenomenon.
\end{abstract}

I seek to show how the meaning of the concept of terrorism changed, following its first use during the French Revolution, coming to be used by established groups to define the 'barbarous' Irish in opposition to the 'civilised' English. I explain how this antithesis was, in part, used as a justification for English 'civilising offensives' in Ireland, while at the same time, wider structural inter-state relations between England and France also contributed to the English seeking monopoly control in Ireland.

I conclude by showing that these processes were central to the development of terrorism as part of EnglishIrish relations during the twentieth century, including how the main groups involved became ensnared in a 'double-bind'.

Key words: Terrorism, established-outsiders, sociogenesis, double-binds, Ireland

In this paper, I will explore the sociogenesis of 'terrorism' in the context of 'established-outsider figurations' that included English elites, and groups of largely Irish Catholic [1].[\#N1].opponents to the imposition of centralised rule from London during the nineteenth century. What follows is a discussion based on research I undertook for my doctoral thesis, completed in 2014, which used time series data gleaned primarily from newspapers (predominantly the London Times).

Ahead of exploring the sociogenesis of terrorism as part of English-Irish [2][[\#N2]_established-outsider figurations in greater depth, it is important to note why newspapers and documentary sources are suitable for such an endeavour. Newspapers and documentary sources can help in developing an understanding of longterm social processes, as they, in effect, provide us with a window into the past. Moreover, a figurational approach to the analysis of documents provides an opportunity to examine the potential position(s) particular documents might occupy within a multitude of interdependencies. Accordingly, a central question in this regard is to ask what social relationships would be involved in the creation of this or that document (see Goodwin and Hughes 2014). These sociogenetic questions allow for an examination of long-term social processes, in this case 'terrorism. For example, The Times newspaper can be said to represent the views and beliefs of many 'established' groups in the United Kingdom, including those at the core of the British polity. Therefore, these kinds of documents help us to develop an understanding of the series of social relations in which 'established' and 'outsider' groups found themselves when the documents were produced.

Before looking in more detail at the sociogenesis of terrorism as part of English-Irish relations in the nineteenth century, I will explain, briefly, how a figurational approach can contribute to the body research on 'terrorism' by detailing some of the major flaws associated with what Jackson, Smyth and Gunning (2009) have described as 'mainstream terrorism theories'. This is an important exercise for at least two reasons. The first is that it will show the reader the extent of research in this area. But more importantly, these mainstream 
positions tend to reproduce the same established group narratives about terrorism this paper seeks to understand.

Following this, I then discuss how the concept of terrorism, after it was first coined during the 1789-1799 French Revolution, changed from being used in a positive sense by the French state [3]_[\#N3]_to a negative one used by established groups in England to describe Catholic Irish outsiders.

I then present evidence of the sociogenesis of terrorism in the context of English-Irish relations drawn from the archives of The Times. From this material, I will explain how inter-state established-outsider relations involving England, France and Ireland in the eighteenth and nineteenth centuries played a central role in the sociogenesis of terrorism (see Dunning, 2014: 105), which was at that stage becoming to be regarded as in antithesis to the idea of 'civilisation'. I will then show how English 'civilising offensives' in Ireland (see Van Krieken 1999) were crucial in this regard. I conclude by examining how the sociogenesis of 'terrorism, as part of English-Irish relations during the nineteenth century, has contributed to more recent terrorism-related figurations involving England and Ireland.

Although the concepts used in this paper will be understood by those readers who are familiar with Norbert Elias's work, there will be others who are less familiar. Accordingly, I will now give a brief explanation of some of these terms for the purpose of clarity.

\section{Sociogenesis}

Sociogenesis is one of the figurational concepts used most widely in this article. It means, quite simply, social generation. It refers to the ways in which relations and processes develop at levels of integration and interdependence on the social level. Sociogenetic changes are also interdependent with what Elias (2012) refers to as psychogenetic changes, which involve development at the level of the psyche. Identifying the sociogenesis of concepts, according to Elias (2009: 46), can reveal wider structural changes in human relations. In the present case study, the changing meaning of the concept of terrorism reveals the changing function of the word for those who used it. For example, it was used at various times in the nineteenth century by established groups in England to describe rebellious Irish Catholics. This functioned for the English, and more broadly British, establishment as a means of stigmatising and delegitimising a group that represented a threat to their interests and dominance, especially at a time, during the nineteenth century, when other elite groups across Europe were being challenged from below.

\section{Established-outsider figurations}

The existence of established-outsider figurations is another fundamental concept in this paper. This set of interdependencies are the central relationships that drive the sociogenesis of terrorism both in terms of the concept of terrorism itself and the wider relations within which that concept is deployed. Accordingly, established-outsider figurations are key in the relationships and, therefore, balances of power between

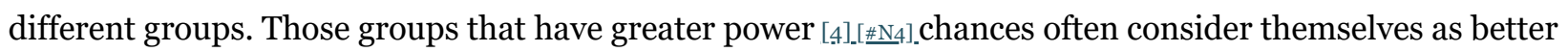
human beings than other interdependent groups who have fewer power chances. The established are better able to manipulate outsiders than outsiders are able to manipulate the established. The established believe their own groups have special virtues, which they see as lacking in others. In fact, groups with fewer power chances are sometimes dehumanised and said to be 'dirty' and 'anomic' (see Elias and Scotson 1994: xxiv$\mathrm{xxx}$ ).

Elias and Scotson (1994: $\mathrm{xx}$-xxi) propose that established-outsider figurations are variable and dependent on the ability of established groups to monopolise positions of power, including government, production and violence. The greater the grasp that established groups have on such areas of social life, the larger the disparity between them and outsider groups. In order to maintain this position, established groups often 
deploy stigmatising language against outsiders, which can enter the self-image of the outsiders, disarming them and reducing their effectiveness in trying to counter-stigmatise. This is a form of what Elias and Scotson (1994: 89) refer to as 'blame gossip', which is used to denigrate outsiders. Conversely, established groups use 'praise gossip' to describe the special virtues of their own group. Counter-stigmatisation can become effective if the balance of power changes between an established and outsider group. For example, an established group may be challenged by another established group, which may make it more reliant on an outsider group, therefore, changing the balance of power between them. This process appears to have been the case in the context of established-outsider figurations involving the English, the French and the Irish during the nineteenth century.

\section{Double binds}

When groups are in competition with each other, they can become locked into processes whereby the structure of their relationships encourages a march towards conflict, in which fantasy ideas about the other increases, which encourages further 'irrationality' towards one another. Elias (1987) refers to these as 'doublebind processes'. These are social processes whereby, for example, two or more interdependent social groups become locked into a conflict that none of them can fully control. This inability to control, and fear of, the other side can lead to highly emotive responses that are laden with fantasy images of the other group. In many instances where relationships assume a double-bind with an attendant spiralling towards violent confrontation, one or more of the groups involved refers to the other as terrorists.

\section{The flaws in research on terrorism in an English-Irish context.}

When examining the sociogenesis of terrorism in the context of English-Irish relations it is important to show how this fits in with previous research on the problem. This invariably leads to a more general critique of terrorism research, because that research tends to fit within a standard paradigm of what terrorism is.

Accordingly, there has been a significant amount written on terrorism with respect to English-Irish relations, including many insightful analyses on the historical developments of these relationships. In his sociological research on terrorism, Vertigans (2008: 72), from a figurational standpoint, cites several examples including: Bishop and Mallie (1988), Bruce, (1992), Coogan (1995), Crawford (2003), Cusack and McDonald (1997), English (2003), McDonald and Cusack (2005), Moloney (2002), Taylor (1998, 2000) and Toolis (1995). In addition to those cited by Vertigans, other examples of research on terrorism involving the British and Irish include: Bowyer-Bell (1997), Heskin (1994), Horgan (2005, 2009, 2013), and McKittrick and McVea, D (2012). Most of these authors have backgrounds in journalism, while some are academic historians, psychologists and political scientists. Of those cited above, apart from Vertigans, just one - Steven Bruce - is a sociologist. This pattern reflects a wider dearth of sociological investigation into terrorism, a subject which has tended to have been dominated by political science and psychology. Vertigans (2011: 13) has previously concluded that sociology's contribution to our understanding of terrorism has been severely restricted.

This state of affairs has particular implications for a more generalised understanding of terrorism and our understanding of specific conflicts like those between the English and Irish. For example, one of the problems with so-called mainstream research on terrorism is that it can contribute to the perpetuation of double-binds by supporting a standard understanding of what terrorism is. This understanding, for the most part, tends to fit closely with how established groups and governments view terrorism. However, this view is not necessarily congruent with reality. In other words, it can become closely associated with fantasy-based knowledge as part of a series of double binds that established and outsider groups are locked into.

There is not space here to go into much detail about the many problems associated with mainstream terrorism research, although it will be useful to touch upon some of the issues, as this may help to show why a 
figurational approach to terrorism in the context of English-Irish relations is an important step to gaining more reality-congr [5][\#N]_ent5 knowledge of the problem.

Crucially, these mainstream approaches tend to define terrorism in ways that are the same or differ only

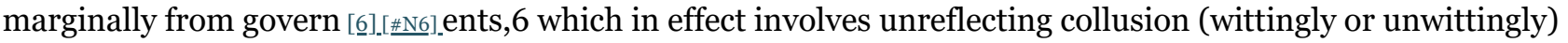
with established group definitions of terrorism. As an example, the political scientists Schmid and Jongman, combine a variety of academic definitions and to come up with the following definition:

Terrorism is an anxiety-inspiring method of repeated violent action, employed by (semi-) clandestine individual, group, or state actors, for idiosyncratic, criminal, or political reasons, whereby - in contrast to assassination - the direct targets of violence are not the main targets. The immediate human victims of violence are generally chosen randomly (targets of opportunity) or selectively (representative or symbolic targets) from a target population, and serve as message generators. Threat- and violence-based communication processes between terrorist) organization, (imperiled) victims, and main targets are used to manipulate the main target (audience(s)), turning it into a target of terror, a target of demands, or a target of attention, depending on whether intimidation, coercion, or propaganda is primarily sought (Schmid and Jongman 2006: 28).

Schmid and Jongman, like other mainstream theorists of terrorism, see terrorism as consisting of a number of properties such as 'violence', 'communication' 'intimidation'. Such definitions are essentialistic and static. This means they cannot be applied to everything that has been called 'terrorism' since the inception of the concept, as a much broader range of social phenomena have been referred to as terrorism in various spheres, as we shall see, for example, in the context of English-Irish relations.

Stampnitzky (2013) demonstrates the hold on terrorism research that mainstream theorists and governments tend to have. She (2013: 23) argues that, in the mid-1970s, peer-reviewed articles on terrorism' began to be produced and that the government of the United States of America began to fund research, which included giving contracts to the RAND corporation. Also during the 1970s, a number of prominent terrorism experts emerged. Stampnitzky points out that this included the following:

Brian Crozier (with a background in intelligence/counterinsurgency), Ted Gurr, a political scientist well-known for his work on collective action, including the acclaimed work Why Men Rebel, Martha Crenshaw Hutchinson (an academic political scientist who had studied the Algerian resistance and would become one of the key figures in the terrorism studies field), Brian Jenkins, a former special forces officer in Vietnam who had become RAND's top expert on terrorism, Paul Jureidini, an expert on the Palestinians who had consulted with DOD and State Departments, and Paul Wilkinson and J. Bowyer Bell, both university-affiliated political scientists (Wilkinson would become head of a terrorism research center at the University of St. Andrews in Scotland, while Bell was employed as a researcher and adjunct instructor at Columbia) who would go on to become central figures in the terrorism studies field (Stampnitzky 2013: 16).

Stampnitzky (2013: 17-18) adds that the tone of debate among 'terrorism experts' changed in the 1970s. At this time, there was a growing consensus that terrorism could not be undertaken by states, but rather only by 'sub-state' groups. Accordingly, terrorism could never by regarded as 'freedom fighting'. Relatedly, we can see that this change is evidence of the sociogenesis of terrorism as an academic concept.

Stampnitzky (2013: 18-22) argues that the tone of debate changed for two slightly contradictory reasons. The first is because terrorism researchers were seeking to make terrorism, 'a precisely defined object of scientific analysis'. The other was because terrorism was being increasingly defined in moral terms. With respect to the former, attempts were made in the 1970s, according to Stampnitzky, to create a stable definition of terrorism, 
which would allow for the collection of quantitative data and for comparative historical analysis. This, she states, allowed terrorism to be understood rationally and to be known through scientific methods. At the same time, according to Stampnitzky, terrorism was being defined in moral terms, which was driven by the interests of governments. These definitions saw terrorism as only being undertaken 'from below' and that it could never be justified. So, on the one hand, there were attempts at more precise definitions of terrorism which was increasingly being seen as an object of scientific study, while on the other the definitions were at the same time being driven by the moralistic concerns of nation states.

However, more recently, and in relation to the United States of America especially, the actions of nation states are being considered as terrorism, as they had been more regularly before the 1970s. Chomsky (2007: 44), for example, has argued that, if using the United States own definition of terrorism, then it too should be considered a terrorist organisation. But even so, the majority of research still focuses on the actions of nonstate groups.

Similar to Stampnitzky, Reid and Chen (2007: 42-56) have claimed that there were 42 'core' terrorism researchers between 1965 and 2003. Citing Reid and Chen's work, Ranstorp (2009: 20) has said that this 42 coalesced around a top ten 'core' of terrorism researchers, who were at the heart of the development of the field.

This insular network of self-appointed terrorism experts has helped to grow and consolidate established group narratives of terrorism as a problem that it, for the most part, emanates from relative outsiders. As a result, narratives of terrorism have been used on many occasions to legitimise government actions, which have often been violent and have included invading countries, repressing certain groups and torture under the pretext of 'wars on terrorism'. In recent times, the United States of America launched a 'war on terror', during which time it invaded Afghanistan and Iraq and bombed several other countries. Colonel Gaddafi, before his death and when leader of Libya, said he was fighting 'terrorists' as people revolted against his rule, as has President Assad during the revolution in Syria, even before the so-called Islamic State came to prominence.

\section{How the concept of terrorism changed from being a term used solely during the French revolution to one used in English-Irish relations.}

The problem of terrorism, as defined by ruling elites both past and present, has also played a significant role in English-Irish relations for around two centuries. In fact, soon after the term was first coined during the 1789-1799 French Revolution it began to be used by established groups in England to describe the actions and characters of certain outsider groups in Ireland. However, in its earliest phase, the word terrorism was used in a positive sense by French revolutionary Maximillien Robespierre as part of a policy that aimed to cement the Jacobin aims of the revolution (see Laqueur 2001: 6) It was used by Robespierre to describe the policy of violently defending 'virtue' and purging anyone he regarded as an enemy of the revolution. He said the following:

...[V]irtue, without which terror is evil; terror, without which virtue is helpless... Terror is nothing but justice, prompt, severe and inflexible; it is therefore an emanation of virtue. (1794, cited in Hoffman, 2006: 3).

How did the change in the function of the concept of terrorism come about from being used in a positive sense by Robespierre to a negative one in both France and Britain? In France, the internal politics of the revolutionaries had a significant bearing on this change in meaning. Competition between the different revolutionary factions in France saw the removal and execution of Robespierre in July 1794 in what was known as the 'Thermidorian Reaction'. It was at this point, according to Laqueur (2001: 6), that the term 'terrorist' became one of abuse with 'criminal implications'. Accordingly, a change in the power relations 
between competing French revolutionaries meant that the concept of terrorism came to be associated negatively with the group (the Jacobins) that had first used it in a positive sense but had at that point lost some of its power potential. Terrorism, in other words, was now associated with a group perceived as being weaker and more anomic.

In England, attitudes among established groups were split, with some supporting the revolution. This included radical Whig politicians and dissenters from the established church (Claeys, 2007: 9). However, according to Claeys (2007: 6), official rejection of the Revolution's principles was so strong that it lasted for almost the whole of the nineteenth century. The United Kingdom, along with several European monarchies also fought wars against revolutionary France during the period.

The views of the prominent Whig politician, Edmund Burke, summed up the attitude towards revolutionary France by many established groups in Britain and Ireland. Referring to events in 1793, he said the following:

To secure them further, they have a strong corps of irregulars, ready armed. Thousands of those Hell-hounds called Terrorists, whom they had shut up in Prison on their last Revolution, as the Satellites of Tyranny, are let loose on the people. The whole of their Government, in its origination, in its continuance, in all its actions, and in all its resources, is force; and nothing but force. (Burke 1999: 359).

Burke's use of stigmatising language to describe the revolutionaries is a form of 'blame gossip'. We can see, therefore, that the concept of terrorists is being used in the context of attempts to stigmatise and delegitimise, as part of the relationships between established groups in Britain and Ireland and the French revolutionaries, who were relative outsiders. There is, therefore, a clear change in the function of the concept of terrorism from its original use.

Evidence from The Times gives us an approximate time at which this change was taking place. The following extract is from 1835 :

The means adopted to prevent the Knight of Kerry's election chiefly demand observation - they are so monstrous and unparalleled, so far beyond the range of election warfare, as to have attracted the attention, we may say, of the empire... We acknowledge, with pride and thankfulness, that the Knight of Kerry ranks among his supporters individuals who have nobly and generously forgotten minor differences, and buried all personal questions under a common determination to resist a system of terror, alike subversive of the freedom of election and the just influence of property.

To preserve the threatened peace of this country, and indeed the lives of the voters, the following formidable array of troops is concentrated in and about Tralee, 2 troops of the 4 th Dragoon Guards; 2 troops of the 7th Dragoon Guards; 4 companies of the 37th Regiment, and two companies of the 31st Light Infantry, from the Cork district, under Captains Flamank and Hanley. The necessity of this protection in the frightful state to which Mr. O'Connell's reckless measures of terrorism have reduced the country, may be judged from an unfeeling paragraph in the Tralee Mercury, a decidedly O'Connellite paper, that exults in the mischief he has caused:--“A party of Dragoons left here this morning for Dingle, whence they are to escort the three Iveragh freeholders, who are going to vote for the Knight...

In the midst of all the notorious ruffianism which these troops are obliged to be employed in repressing, Morgan John O'Connell has the hardihood and hypocrisy to put forth an address, declaring--“I am a Reformer of all abuses”. (The Times, 22 January, 1835). 
We can see from this article that the Irish group led by O'Connell, in addition to being said to undertake 'terrorism' are also stigmatised by The Times as being 'monstrous' and 'ruffians'. The use of the label terrorism, to describe their activities, alongside other stigmatising terms helps to demonstrate further the context in which it was deployed. That is, put simply, as a delegitimising term of abuse. The article clearly paints whatever O'Connell and his followers have done as wrong. At the same time, those who were stigmatised in The Times article are also unfavourably compared to the supporters of the Knight of Kerry who are said to be 'noble'. In response, The Times reports that a 'formidable array of troops' is used by the empire to 'repress' the 'ruffianism'.

As with the change in function from the use of the concept of terrorism during the French revolution to its use in English-Irish relations shortly after the revolution, it is important to note that, over the course of the last 200 years designations of terrorism have continued to change. Recognising that designations of terrorism change over time, means the concept can be regarded as both relational and processual, and expresses certain dynamic figurational conditions through which some groups are related to each other. That is, if an established group labels an outsider group as terrorist and that label sticks over time and resonates with members of both groups, then it can be argued that there are particular relationships at play between these groups that tend to have certain structural regularities. These relationships are similar to other instances when other 'established' groups 'successfully' label other 'outsider' groups as terrorists. When labels such as terrorism stick, they tend to do so as part of dominant narratives, and it is elite group narratives that tend to be dominant within a broad range of figurations that include both established and outsider groups. The point therefore, is not the perceived 'properties' of terrorism but the relationships between groups.

\section{The historical context of 'terrorism' as part of English-Irish relations}

Established group narratives concerning terrorism, in particular, in the English-Irish context began to develop in the first half of the nineteenth century. However, the relationship between ruling elites in Britain (and relatedly ruling elites in Ireland of British extraction) and 'outsider' groups in Ireland has a much longer history, and one that pre-dates the formation of Britain. It is important, therefore, to note, in a bit more detail, the historical context to the development of English-Irish terrorism figurations. Accordingly, in medieval and what is referred to as early modern Europe, during both integrative and disintegrative processes of state formation, parts of Ireland came under the control of the rulers of England and later Britain. (This period predated the formation of the United Kingdom of Great Britain in 1706-7 following the acts of union between the kingdoms of Scotland and England.) They attempted to impose 'civility' on the Irish as part of a process known in the sixteenth and seventeenth century as plantation [7][\# [\#]_.7 which involved the colonisation of Catholic Ireland with English and Scottish Protestants. Discussing late sixteenth and seventeenth century plantation, English says:

It involved the colonization of Irish land by settlers planted here from England and Scotland. For the settlers, new opportunities were available in the new land; for the authorities, the colonies would offer many supposed benefits: security against foreign attack, control of the local population, defence of royal interests, the stimulation of economic development, and - perhaps above all - an exemplary model of civility and true (Protestant) religion would have a transforming effect on the barbarous Irish (English 2006: 58).

Significant numbers of newcomers were settled in Ireland through plantation. For example, according to English (2006: 58), by the middle of the seventeenth century 20,000 English people had been relocated to Munster and around 15,000 English and Scots in Ulster. But the process of plantation was still unable to fully pacify the country and bring it under control by established groups in England. There were rebellions against Protestant landowners in the seventeenth and eighteenth centuries. English (2006: 60) points out that one of 
the most prominent of these was in 1641 during which Gaelic Irish and Old English (Anglo-Irish) Catholics rose up and killed an estimated 4,000 Protestant settlers. However, in 1800-1, under the leadership of Prime Minister William Pitt, the Irish Parliament was dissolved and Ireland was incorporated into the United Kingdom of Great Britain and Ireland.

\section{Newspaper examples of the sociogenesis of terrorism as part of English-Irish relations in the nineteenth century.}

Terrorism developed in the context of British rule in Ireland and its sociogenesis can be traced in newspaper reports from The Times (examples to follow), which demonstrate how established-outsider figurations between English elites and rebellious Irish Catholics manifested themselves in an established groups mouthpiece. The Times printed what could be described as a form of 'praise and blame gossip' about the 'civilised' English and 'barbaric' Irish Catholics.

Accordingly, in an article from The Times (12 November 1835), Catholic priests are described as terrorists. The report claimed that Ireland's Roman Catholic provinces exhibited a 'diseased constitution of society', and that priests and other Catholics are 'evil'. It added that there are two possible outcomes: that 'either Popery puts down the State, or the State, in self-defence, must crush it'. These two possibilities clearly show how established-outsider relations in Ireland at the time were being manifested - as a sometimes violent struggle between established groups in Britain and Ireland and rebellious Irish Catholics. The article went on to claim that Catholic priests are 'pious terrorists' and commit acts of 'savage cruelty.'

These attitudes towards the priesthood in Ireland and Catholics in Ireland more generally, were reflected in the language used in several debates on Ireland in the Houses of Parliament. For example, during one (Hansard 04 May 1838) in the Lords, Catholic priests were described as 'overbearing, tyrannical, bigoted and implacable', and three provinces in Ireland were described as 'barbarous'.

A decade later, in 1845, The Times, in another article, juxtaposed Ireland with England and said that English people were ordered and submissive to the rule of law, but, in many Irish districts, at this time, the opposite was the case. These districts were said to be lawless and where terrorism was undertaken by opponents of British rule. The language used by The Times, was part of the general trend in which established groups in England and Ireland regarded the English as 'civilised', but also that at least parts of Ireland were 'uncivilised' or 'barbaric'. We can see, therefore, how the concept of terrorism continued to develop in antithesis to the concept of 'civilisation', as part of the wider figurations involving established and outsider groups in England and Ireland.

In an 1865 Times article, references to 'Fenians' were prominent. The Fenians were groups of Irish revolutionaries who attempted to oust the British from Ireland following a period in which Daniel O'Connell had failed to repeal the 1800-1 Act of Union by political means. According to English (2006: 180), a commitment to separatist violence was central to how Fenian groups believed they could rid themselves of the British. In order to achieve this, the various Fenian groups sought to cultivate relationships with both France and America, and were particularly successful with the latter. This shows that the established-outsider figurations between the English establishment and rebellious Irish Catholics were more complex than at first appears. These relations, therefore, have to be understood in the context of multi-polar inter-state figurations, which also involved France and America and means that many of the decisions and moves by established groups in England and Irish Catholic rebels have to be understood in the context of the decisions and moves by France and America, which I shall discuss shortly.

There were a number of violent uprisings associated with Fenian groups. The following extract in The Times mentions Fenianism in relation to 'terrorism': 
On Wednesday the affray at Dangan between the constabulary and the Fenians again engaged the attention of the coroner, who resumed his enquiry into the circumstances attending the death of Samuel Kelly, who was shot on the occasion. The Courthouse at Midleton was densely crowded and the greatest interest manifested in the proceedings. It is stated, however, that evidence in favour of the police is difficult to be obtained in consequence of the terrorism exercised over the minds of the people of Fenianism (The Times, 19 August 1865).

The Times' use of the word terrorism in this context seems to follow on from its earlier descriptions of Catholic priests. That is, by claiming that 'terrorism' is 'exercised over the minds of the people of Fenianism', the suggestion is that 'terrorism' in this context is equivalent to intimidation and threats, rather than fulfilling the kind of criteria that present-day definitions tend to require.

In another Times article published in 1870 (23 February p.12a), the concept of terrorism is again used in relation to Fenianism [8][Nㅛ] and is again equated with intimidation. Terrorism as intimidation, of course, does have some similarities with some aspects of contemporary definitions, but obviously differs in a number of other ways. For example, there is no reference to bomb attacks targeting civilians in order to communicate the terrorists' aims. This suggests that the concept of terrorism, during this period, was less technical than it is today, and more of one that was being used specifically in antithesis to the civilised English. In other words, it was more clearly relational.

During the same period, according to English (2006: 203), a group of Fenians were involved in setting up the National Land League and protested about rents in using both legal and illegal means, including the withholding of rent. The Land League's objectives and tactics were frowned upon by members of England's ruling elite, the evidence for which is visible in a Times article of 18 October 1880, which suggested that the Land League undertook terrorism, created 'anarchy', was 'uncivilised' and perpetrated 'monstrous oppression'. The use of the word 'anarchy', along with terrorism and contrasting Irish terrorism and anarchy to 'civilised' behaviour is interesting in this context. Its use reflects the concern on the part of established groups across Europe with the existence of anarchist groups, and their activities. These anarchists were also deemed as terrorists by Britain's ruling elite. This 1880 Times article correspondingly suggested a conflation of 'Irish terrorism' with the 'anarchist terrorism' perceived as occurring across Europe (see also The Times, 26 January 1885). This conflation provided an over-simplistic picture of what were, in fact, continent-wide structural changes, painted by an established group mouthpiece like The Times, and was clearly useful propaganda for the maintenance of the status quo at the time. It had the function of blame gossip, while at the same time helped to reinforce established groups' feelings of superiority by juxtaposing the 'terroristic' Irish and Anarchists with the 'civilised English', therefore strengthening the collective bonds between members of the established groups.

In another Times article on 19 October 1880, it was reported that a Conservative MP claimed that Ireland was governed by a 'system of terrorism' and that it was important that the British Empire should 'stem the tide of democracy'. This is further evidence of the view that England's ruling elite had of Ireland, and, at the same time, exposes how circumstances in Ireland were being compared to circumstances in France during the French revolution. The idea of 'a system of terrorism' in Ireland suggests this, as Robespierre and the Jacobins operated what they referred to as the régime de la terreur, roughly translated as 'system of terror' or 'reign of terror'. The concept of a 'system of terrorism' was used by established groups in England to stigmatise and delegitimise their enemies in Ireland. That established groups in Britain used the term 'system of terrorism' to describe both the French Revolutionaries and Irish 'revolutionaries' in a negative way shows that they held both with a high level of contempt. They were, in effect, saying that their Irish enemies were as bad as, and comparable to, their French revolutionary enemies previously. In addition, the idea that the tide of democracy needed to be stemmed demonstrates a degree of fear among ruling elites that a push towards greater democracy by 'outsider' groups would threaten their position. As such, they attempt to stigmatise and delegitimise outsiders by claiming that they are terrorists who operate a 'system of terrorism'. 
In their attempts to gain Irish independence, the Fenians, undertook a bombing campaign on the British mainland, with a focus on London. For example, on 1 November 1883, The Times reported the bombing of the Metropolitan and the Metropolitan District Railways in London and said that this was a declaration of war against civilisation and social order. In the article, The Times claimed that this and other bombings had one markedly different aspect to them and that was that they targeted the masses, including the working classes. However, it also points out that it had not been proven that it was 'Irish terrorists' that were behind the bombings, but that they were the likely suspects, together with the possibility that it may be anarchists from elsewhere in Europe. Nevertheless, these kinds of attacks tend to correspond much more close to modern day definitions of terrorism than the other examples shown above.

Accordingly, terrorism figurations in Britain by the late nineteenth century had become far more multidimensional than in the past. Links are made in The Times (26 January 1885) between anarchist or communist terrorism with Irish nationalist terrorism, as well as the relationships between Irish Catholics, Irish-Americans and Britain. This clearly shows that, in the context of Ireland, the structural characteristics of terrorism figurations in Britain had moved on from less complex relationships between established groups in England and Ireland, and 'outsider' French revolutionaries and rebellious Irish Catholics to more global figurations. These encompassed Britain's transatlantic relations with America, together with relationships across Europe, including Ireland, France, Russia, and other countries where communist and anarchist outsiders were regarded as a threat.

That groups which were, in terms of power chances, relatively weak, were by the mid- to late nineteenth century able to bomb Britain, as is the case with English-Irish terrorism, shows that the power differentials between the ruling groups and those much lower down the social scale were shifting slightly in favour of the latter. In addition, established groups were fearful of an equalisation of power chances between themselves and groups lower down the social scale. As a result, they sought to delegitimise and stigmatise them, including by calling them terrorists.

This process of an evening up of the balances of power between established and outsider groups is dealt with by Elias (1994: xx-xxi) in a discussion about stigmatisation and counter-stigmatisation. Elias argues that, in the case of very uneven balances of power, if there is enough of a shift in the balance of power towards outsiders, they are in a position to be able to retaliate and counter-stigmatise. In the case of English-Irish figurations, in which terrorism played a part, the retaliation by the outsiders included the ability to bomb mainland Britain. Nevertheless, the relationships at the time, between established groups in England and outsiders in Ireland still remained highly asymmetrical, as was the case with past and more recent bombing campaigns by Irish Catholic outsiders.

\section{The structural context of nineteenth century English-Irish terrorism figurations.}

Crucial to the conflicts involving established groups in England and outsider Catholic Irish groups in the nineteenth century were a variety of related inter- and intra-state processes. Accordingly, inter-state competition between the rulers of what became the United Kingdom of Great Britain and Ireland in the nineteenth century (following the Acts of Union 1800-1), and their rivals, especially in France, formed part of much longer processes. These processes, according to Elias (2000), involved the monopolisation of physical

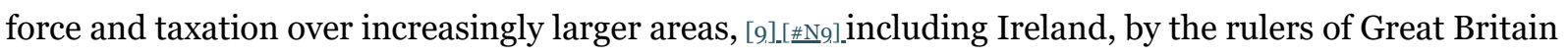
(Britain) and have been central in this regard.

Both Britain and France had developed the characteristics of what are called modern states by the late eighteenth and early nineteenth century, meaning that the populations in the geographical areas now called 'France' and 'Britain' came under the control of centralised, monopolistic governing structures in the guise of monarchs and parliaments, and that the apparatuses of physical force and taxation were under the control of these centralised authorities (see Elias's discussion of the 'monopoly mechanism', 2012: 301). But this did not 
mean that competition was over; there were still inter-state pressures between these two powerful states. Those pressures contributed to wars between the two countries following the 1789-1799 French revolution and a rejection of the principles of the revolution in the United Kingdom by many elite groups, including those led by prime ministers (including William Pitt the younger, 1783-1801 and 1804-1806, and Henry Addington 1801-1804), the King (George III, 1760-1820) and the military. Furthermore, the competition between the two countries also encouraged them both, at various times, to increase the areas covered by their monopolies of violence and taxation by colonising other countries. Britain, for example, expanded its monopoly of violence and taxation in the nineteenth century to Catholic Ireland and became the United Kingdom of Great Britain and Ireland (United Kingdom), This was, in part, to help protect itself from invasion from Catholic France. Therefore, the competitive and interdependent relationships between Britain and France played a significant role in the relationship between Britain and Ireland. As such, all three countries formed part of the same inter- and intra-state figurations. English elites, as mentioned, were never able to fully subdue the rebellious Catholic Irish in the same way that other groups had been brought under monopolistic control across Britain. As already alluded to, established groups in England in this context regarded themselves as 'civilised' but saw outsider Irish Catholics as the antithesis of themselves. Accordingly, as part of stigmatising and delegitimising language that they deployed against rebellious Irish outsiders was the label, terrorists. This helped to feed into the 'double-binds' within which these competing groups were enmeshed.

\section{Civilising Offensives in Ireland}

As evidence from the newspaper reports shows, England's attempt to pacify Ireland was not only for instrumental reasons related to competition with France. It was also an attempt to 'civilise' what many established groups in England saw as a 'barbaric' people. The English undertook what Van Krieken (1999: 297) describes as 'civilising offensives'. Civilising offensives, says Van Krieken are, 'self-conscious attempts to bring about 'civilisation', and have revolved around essentially violent policies and practices.' They are attempts by established groups to, on the one hand, dominate outsider groups, and on the other assimilate them into their own standards of conduct. Civilising offensives are often violent and have been practiced on both the intra and inter-state levels. Violence tends to be more likely on the inter-state level due to the lack of 'violence controls' on that plane (Elias 1987: 74-75; Linklater 2010: 157)

As was discussed earlier, English civilising offensives in Ireland have a long history, including through the process of plantation. In fact, English (2006: 57) points out what could be described as 'civility offensives' during the sixteenth century. He argues that the sixteenth century English poet and Irish landowner, Edmund Spenser, epitomised the sentiments of the ruling elites in England towards Ireland at the end of the 1500s, in his epic poem The Faerie Queene (1590-96). English highlighted the following:

Religious reform and political subjugation were as one here, as reflected in Spenser's allegorical epic The Faerie Queene (1590-96). This stressed the benefits of violence when deployed for truly worthy causes, and indeed emphasized that the righteous must be prepared so to use violence against evil. Force had proved historically necessary in order that civility should defeat barbarism, and Spenser presented a single British world as having been created - through conquest - out of the varied materials of England, Scotland and Wales. Within this portrait, England had an historic mission to defend civility and genuine Christianity, and to do so through the production of a unitary state within the islands of Britain and Ireland (English 2006, 57).

The points made by English are particularly interesting. For example, he suggests here that violence for Spenser was legitimate and beneficial, if for a worthy cause. Parallels can be drawn between this view and 
Robespierre's, which claimed that terrorism to protect the ideals of the Revolution was legitimate. At the same time, according to Spenser's view, Irish violence, was not legitimate but barbarous.

Accordingly, Van Krieken discusses English civilising offensives in Ireland and explains how the English conception of barbarism developed in antithesis to civilisation in the Irish context and was then deployed during the colonial conquests of the British Empire. He argues the following:

'Any cursory look at Irish history makes it clear that it is closely bound up with English state and cultural formation, and that a central element of the English perception of Ireland was a persistent distinction between civility/civilization and barbarism being equivalent to the distinction between the English and the Irish. Indeed English civility was in many respects defined precisely in opposition to Irishness - it was everything that the Irish were not.' (Van Krieken 2011: 31)

Van Krieken (2011: 42) goes on to say that the antithesis between civilisation and barbarism in the EnglishIrish context was placed into stark contrast as part of the processes by which the English in the twelfth century tried to incorporate the 'Celtic fringe' into English society and its political system. He points out that the idea that the Irish were barbarous savages helped to legitimate extreme violence by the English against the Irish as a means of civilising and pacifying them. He argues that this level of violence was practised until at least the end of the seventeenth century, and was then followed-up by subsequent economic exploitation during the next two centuries. Crucially, says Van Krieken, Ireland became a kind of test bed for English and later British colonial practices. He says, in fact, that the English used 'decivilising techniques' in this context to try and 'civilise' the Irish.

This is an important point, in that such techniques would be fundamental to reciprocal violence or nonviolent rebelliousness committed by Irish Catholics against the English, which was then designated as terrorism and formed double-binds of increasing hostility and violence between the competing groups. In the circumstances discussed here we can see that civilising offensives contributed to the development of terrorism. In this sense, English violence was seen as acceptable and just, whereas Irish violence was regarded as barbaric. A central reason why English violence in this context was and is regarded as more legitimate than Irish Catholic violence, is because the English establishment had greater power potential than the Irish, and were better able to make stigmatising labels stick, meaning they could better determine what was legitimate and what was not within the overall figuration.

\section{Conclusion: How the sociogenesis of terrorism as part of English-Irish relations in the nineteenth century underpinned the development of terrorism in post-partition Ireland.}

The sociogenesis of terrorism as part of English-Irish relations during the nineteenth century was central to how the relationships between the different groups continued to develop over the subsequent century, including, crucially after the Irish war of Independence (1919-1921) and the creation of the Irish Free State (now the Republic of Ireland) and Northern Ireland.

Discussing how figurations develop, Elias (1978: 161-162) talks about how earlier figurations are preconditions for later figurations. Accordingly, the figurations formed by the English and the Irish prior to the partition of Ireland were preconditions to subsequent later figurations in the context of those relations. This is an important point, as many present-centred approaches to the social sciences tend to look at individual causes over much shorter timeframes. 
Accordingly, the sociogenesis of terrorism in the context of English-Irish relations in the twentieth century continued along similar lines to that of the nineteenth century. The structural context continued to reflect a predominantly uneven balance of power in favour of England as part of established-outsider figurations between the two territories. However, that balance of power began to even up to a degree and one of the most prominent examples of that was the creation of an independent Ireland following the Irish War of Independence. This involved the partition of the island and, as a result, the figurational dynamics changed. Following this period, the British Empire was declining and the Second World War was fought. Additionally, the dynamics of global power relations were shifting significantly too, and, after the Second World War, the bi-polar world of the Cold War emerged, with the Western European colonial nations much less influential than had previously been the case. This was also a time when a number of Irish terrorist organisations continued to gain prominence, including the Irish Republican Army (IRA), which later split into the Provisional IRA and the Official IRA, and again into the Real IRA and Continuity IRA, all of which are/were republican groups. On the loyalist side, among others, there were the Ulster Volunteer Force (UVF), the Ulster Freedom Fighters (UFF), and the Loyalist Volunteer Force (LVF). Nationalist and republican groups who sought a united Ireland took it upon themselves to protect Catholic communities in Northern Ireland from real and perceived threats from Protestants, loyalist groups and the British. Likewise, loyalist groups took it upon themselves to resist the unification of Ireland and to protect the Protestant community from real and perceived threats from republicans.

Broadly speaking, the established-outsider figurations in post-partition Ireland involved four main groups: established groups in Britain, Northern Irish loyalists, the established groups in Ireland and Northern Irish republicans. Vertigans (2011: 130) talks about triple binds in this context, and argues that these were formed between the British state and loyalist and republican terrorist groups.

Accordingly, it would be useful to explain these relationships further. The relinquishing of control over what is now called the Republic of Ireland by the British should be understood as part of the process by which Britain was retreating from its former global dominance, and as such reflects a reduction in the power differentials between the most established groups in Britain and Irish Catholic republicans. However, the situation in Northern Ireland is more complex than that between the just the British establishment and Irish Catholic republicans due to the fact that a large proportion of Northern Ireland's population were and are Protestant and want to remain part of the United Kingdom (unionists). Of course, Protestant unionists were a part of British-Irish figurations prior to partition but their position changed as power differentials, including between them, and Catholic republicans began to even up with the creation of the Irish Free State. As such, established-outsider figurations in the context of the Northern Ireland conflict take on added complexity. For example, the power differentials between unionist Protestants and nationalist and republican Catholics tended and tend to favour the former. Likewise, the British establishment had greater power chances than both of these groups but more closely aligned to the loyalist Protestants for obvious reasons. Other parts of this figurational nexus include the Irish and United States governments, and Irish-Americans, among others. These groups had and have relationships with and sympathies for Northern Irish nationalists and republicans, but also, at the same time some of them, at least, had relationships and sympathies with the British government.

However, the most prominent established-outsider figurations in the Northern Irish terrorism context were and are between nationalist/republican Catholics, unionist Protestants and the British and Irish governments. Although not totally uneven, the power ratios between the Northern Irish Protestants and Catholics were and are significant, with access to better political and economic positions tending to be in the hands of unionist Protestants. Catholics were, accordingly, discriminated against and stigmatised more effectively than any counter-stigmatisation directed by them against Protestants.

The greater power chances of Northern Ireland's Protestants were, in part, a result of their relationship to established groups in England. In fact, they could be said to be close to British established groups due to their political leaders sitting in the House of Commons. As mentioned, these greater power chances, among other things, meant that theirs and the English attempts to stigmatise and delegitimise Irish Catholic republicans 
were far more effective than any counter-stigmatisation attempts by the latter, if we are to understand this within the whole figuration of British-Irish relations. That is not to say that stigmatising language used by Irish Catholic republicans did not hit its mark within the smaller figurations formed between nationalists, unionists and loyalists. The calling of loyalists, unionists or British 'terrorists' in some Catholic communities would have had a large degree of resonance and would have helped to bond those Catholic communities together. But it would have been less likely to have much of an effect on established groups in Britain than stigmatising labels would have had on Catholic communities in Northern Ireland.

The power chances of Northern Irish unionist and loyalist Protestants in relation to the region's republican Catholics have been further enhanced by the history of relations in Ireland. Catholics, for centuries, were regarded as second-class citizens, particularly after the introduction of the Penal Laws from the late seventeenth century; had limited land rights compared to the island's Anglican Protestants, and generally were denied access to higher status occupations and political office. This centuries-long established-outsider dynamic in Ireland as a whole, therefore, was crucial in determining the established-outsider dynamics in Northern Ireland following partition. Spanning back at least to the period of plantation in Ireland in the sixteenth and seventeenth centuries, the figurational dynamics of established-outsider relations had often developed to such an extent that violent confrontation became a regular part of these relationships.

As in most violent confrontations between two or more groups, there tends to be a spiralling of the tensions between them. For example, in the case of Northern Ireland, the separation of Protestant and Catholic communities, together with the unequal power chances in favour of Protestants saw, as mentioned, attempts to stigmatise and delegitimise by both sides. Such processes can, and in this case did, spiral into greater and greater levels of violence, in which the fantasy content of the language used against the other increased. So, for example, Catholic republicans in general tended to be tarred with the 'terrorist' brush by the English, unionists and loyalist Protestants. The same process was evident the other way around, and the British were regarded as occupiers and the real terrorists by the Catholic community. Such spiralling of fantasy-laden suspicions and violence was and is central to double-binds forming in this context and the perpetuation of relationships in which terrorism plays a part.

The double-binds that the people in the United Kingdom and the Republic of Ireland were entwined involved the deployment of stigmatising language against each other. Double-binds in this and other contexts, according to Elias (1987: 67) are reinforced because the deployment of stigmatising language against another group is emotionally satisfying in that it helps to elevate one group above the other. This stigmatising language tends to tar the whole stigmatised group with the characteristics of their most 'anomic' members (Elias and Scotson 1994: xix), and so in the case of the Northern Ireland context this would generally be their most violent members, or terrorists. At the same time, each group tends to ascribe to itself the qualities of its 'best' and most virtuous people. This helps to reaffirm the self-love that groups have for themselves.

Differences between Protestants and Catholics in Northern Ireland were and remain entrenched in a number of ways including in the education system (see Dolan, 2015: 5). Coohill (2008: 160), for example, points out that Protestant children were taught that Britain was 'the good nation' rather than Ireland or Northern Ireland, so that children thought that goodness came from Britain. The Republic was seen by Protestants to be under the thumb of Rome and there was a fear that a united Ireland would succumb to such a fate. Differences were further compounded by the use of stigmatising language used by one group against the other, including calling each other terrorists.

Accordingly, we can see how through an analysis of nineteenth century newspaper articles how the concept of terrorism developed significantly in the context of English-Irish relations. During that period, perhaps the most consistent regularity with the use of the concept of terrorism is that it is seen as the antithesis of 'civilisation'. This was central to how relations between the English and Irish developed throughout the twentieth century. When the concept is deployed by established groups it can have a lasting and delegitimising effect on those on the receiving end, which consequently can help to constrict the double binds within which groups are enmeshed when the term is used. It is only when a way of loosening those doublebinds is found that terrorism tends to become less of an issue, as appears to have been the case in recent 
years, following the Good Friday Agreement in 1998. Only time will tell if the double-binds between Britain, Northern Irish republicans and Northern Irish loyalists have been loosened sufficiently to consign the problem of 'terrorism' in these contexts to the past. But it is still possible that current centrifugal forces in Britain and Europe could potentially contribute to a resurgence of terrorism as part of those relationships. In recent years there has been an increase in violence, including by a group known as the 'New IRA'. A report on the website of The Independent newspaper (11 May 2016) has linked several murders to the organisation. This may suggest that the double binds in Northern Ireland are beginning to tighten again.

1. I shorten English-Catholic Irish established-outsider figurations to English-Irish, as my main concern is how the concept of 'terrorism' developed among established groups in England. This is because, as part of the figurations under discussion, established groups in England have had the greater power potential, and so their use of the concept of 'terrorism' has had greater resonance across a much wider range of human interdependencies. For example, the concept of 'terrorism' was used by the English to describe a range of rebellious groups during the period of the British Empire. The word 'terrorism' is also now used by established groups across the world to describe the actions of 'outsider' enemies. ثิ.[\#N1-ptr1]

2. I am using 'English' here, instead of 'British' as monopolisation processes in the British Isles from the twelfth century, involved what Van Krieken (2011: 33) has described as: 'attempts of the English state to incorporate its Celtic fringe into a centralized polity and society with a relatively homogenous type of "English self".' This process highlights that established groups in England tended to have greater power potential than established groups in the other territories of the British Isles. It is the relationships between established groups in and from England and outsiders in Ireland, during the nineteenth century, that form the core of the discussion in this article. There are places where I make reference to the Anglo-Irish as an established group in Ireland. I use the terms Britain and British in places to describe either the rule of Ireland from Britain or when I refer to the British Empire. I also use 'Britain' to denote the political entity that was formed after the 1706 Acts of Union. I use 'United Kingdom' in places to describe the political entities of Great Britain and Ireland, following the 1800-1 Acts of Union, and in its most recent formThe United Kingdom of Great Britain and Northern Ireland. 苫.[\#N2-ptr1]

3. I am using the word 'state' in the way Elias (2012: 302) used it. That is, the characteristics of a state emerge when a central authority is able to maintain a relatively stable monopoly of physical force and

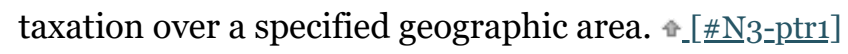

4. Power should be seen as relational and involves the ability by certain groups to monopolise what other, interdependent groups need or are seeking, such as food, knowledge, material wealth, violence and so on. (see Elias and Scotson $\mathrm{xx}-\mathrm{xxi}$ ). ثै._\#N4-ptr1]

5. Reality congruence is a term that recognises that knowledge is derived from research and theories developed by scientific specialists investigating what is 'real', as part of much broader dynamic process of interdependence. It is not something fixed, but focusses on a continuum of knowledge that tends to be either more or less congruent with reality. Dunning, E and Hughes explain what Elias this in more detail: '...the term 'reality congruence' implies a 'process', not a state. It is a 'flow' term not an 'essence' term, one which refers to varying degrees of approximation, of agreement, between the dynamism of scientific knowledge and the dynamism of the social reality of which that knowledge forms part...Elias did not think of 'reality' as something fixed, monolithic and ultimately 'fully knowable'. He did not see it as a 'thing out there', but rather as a dynamic totality which includes humans and their expanding (and sometimes contracting) knowledge as an integral part. It follows that, in Elias's view, knowledge can never be 'absolute', never 'finished' or 'final' as is implied by a static concept like 'truth'. (Dunning and

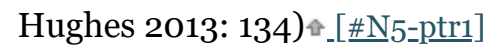

6. For example, the US State Department's definition is as follows:

Title 22 of the United States Code, Section $2656 \mathrm{f}(\mathrm{d})$ :

The term terrorism means premeditated, politically motivated violence perpetrated against noncombatant targets by subnational groups or clandestine agents, usually intended to influence an audience.

The term "international terrorism" means terrorism involving citizens or the territory of more than one country. 
The term "terrorist group" means any group practising, or that has significant subgroups that practice, international terrorism. United States Department of State (2004)스.[\#N6-ptr1]

7. Jennifer Todd (2009) has pointed out that plantation contributed to the following relationships:: '...power relations were tied around religious distinction, legally in the Penal Laws, informally in Protestant resistance to reform. The result was a multiconstituted conflict, where power relations (expressed in military force, economic resources, class position, law and political representation) were partially organised by formal and informal religious institutions and networks, and where symbolic boundaries were multiplex, with religious beliefs, moral-political norms and civilisational values, historical narratives of plantation, and ethno-national identities overlapping if never quite coinciding.' (Todd, 2009: 2). 䜣[\#N7-ptr1]

8. Fenianism is also associated with terrorism in the Houses of Parliament, on a number of occasions, during the second half of the nineteenth century. Ireland, during the period Fenian rebellion is also compared with the reign of terror in France. Evidence for this can be found in Hansard (HC Deb 21 March 1870 vol. 200 cc 328-411) ‥[\#N8-ptr1]

9. Elias (2012: 303) points out that societies tend to be balanced between centrifugal forces and centripetal forces. Until the eleventh century in Europe, centrifugal forces were in the ascendency. However, from that period centripetal forces became dominant. According to Elias, monopoly processes of violence and taxation can be summarised as follows:

If, in a major social unit, a large number of the smaller social units which, through their interdependence, constitute the larger one, are of roughly equal social power and are thus able to compete freely - unhampered by free existing monopolies - for the means to social power, i.e. primarily the means of subsistence and production, the probability is high that some will be victorious and others vanquished, and that gradually, as a result, fewer and fewer will control more and more opportunities, and more and more units will be eliminated from the competition, becoming directly or indirectly dependent on an ever-decreasing number. The human figuration caught up in this movement, will therefore, unless countervailing measures are taken, approach a state in which all opportunities are controlled by a single authority: a system with open opportunities will become a system of closed opportunities. (Elias 2012: 303) ث.[\#N9-ptr1]

\section{References:}

Bell, B.J. (1997) The Secret Army: The IRA. New Brunswick: Transaction Publishers.

Bishop, P. and Mallie, E. (1987), The Provisional IRA. London: William Heinemann.

Bruce, S. (1992) The Red Hand: Protestant Paramilitaries in Northern Ireland. Oxford: Oxford University Press.

Canavan, F. (ed.) (1999) The Selected Works of Edmund Burke: V. 1-3: 'Thoughts on the Cause of the Present Discontents' / 'The Two Speeches on America' / 'Reflections on the Revolution in France' / 'Letters on a Regicide Peace'. Indianapolis: Liberty Fund.

Chomsky, N. (2007) 'Terrorism, American style’. World Policy Journal, 24: 1, pp. 44-45.

Claeys, G. (2007) The French Revolution Debate in Britain. Basingstoke: Palgrave Macmillan.

Crawford, C. (2003) Inside the UDA: Volunteers and Violence. London: Pluto Press.

Cusack, H. and McDonald, J. (1997), UVF. Dublin: Poolbeg Press.

Dolan, P. (2015) Balances between civilising processes and offensives: adult-child relations in Irish primary schools from the mid-nineteenth century. Human Figurations. [Online] 4 (1) Available at: http://quod.lib.umich.edu/h/humfig/11217607.0004.105/-balances-between-civilising-processes-andoffensives-adult?rgn=main; view=fulltext

[http://quod.lib.umich.edu/h/humfig/11217607.0004.105/\%E2\%80\%94_balances-between-civilising-processes-and-

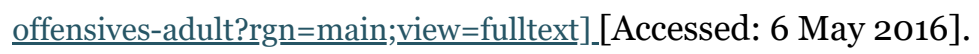


Dunning, E. and Hughes, J. (2012), Norbert Elias and Modern Sociology: Knowledge, Interdependence, Power and Process. London: Bloomsbury.

Dunning, M. (2014) Britain and Terrorism: A Sociogenetic Investigation. Ph.D. Brunel University. U.K. Elias, N. (1978) What is Sociology? London: Hutchinson \& Co.

Elias, N. (1987) Involvement and Detachment. Oxford: Basil Blackwell.

Elias, N. (2009), On the Sociogenesis of Sociology in Essays III: On Sociology and the Humanities. Edited by Richard Kilminster and Stephen Mennell. Dublin: UCD Press (Collected Works vol. 16).

Elias, N. and Scotson, J. (1994), The Established and the Outsiders. London: Sage.

Elias, N. (2012) On the Process of Civilisation. Dublin: UCD Press.

English, R. (2006) Irish Freedom: The History of Nationalism in Ireland. London: Macmillan.

English, R. (2012) Armed Struggle: A History of the IRA. London: Macmillan.

Hansard House of Lords 04 May 1838 vol. 42 cols 898-905.

Hansard House of Commons 21 March 1870 vol. 200 cols 328-411.

Hoffman, B. (2006) Inside Terrorism. New York: Columbia University Press.

Heskin, K. (1994) Terrorism in Ireland: the past and the future. The Irish Journal of Psychology. 15: 2-3, pp. 469-479.

Horgan, J. (2005) The Psychology of Terrorism. Oxford: Routledge.

Horgan, J. (2009) Walking Away from Terrorism: Accounts of Disengagement from Radical and Extremist Movements. London: Routledge.

Horgan, J. (2013) Divided we Stand: The Strategy and Psychology of Ireland's Dissident Terrorists. Oxford: Oxford University Press.

Hughes, J. and Goodwin, J. (2014), 'Human Documents as Figurations'. In: Documentary and Archival Research. London: Sage, pp. 1-26.

Jackson, R. Breen-Smyth, M. and Gunning, J. (2009), Critical terrorism studies: framing a new research agenda. In: Jackson, R., Breen-Smyth, M. and Gunning, J. (eds.) Critical Terrorism Studies: A New Research Agenda. Oxford: Routledge, pp. 1-9.

Laqueur, W. (2001) The History of Terrorism 2nd ed London: University of California Press.

Linklater, A. (2010) Global civilizing processes and the ambiguities of human interconnectedness. European Journal of International Relations. 16: 2, pp. 155-178.

McDonald, H. and Cusack, J. (2005), UDA: Inside the Heart of Loyalist Terror. Dublin: Penguin Books.

McKittrick, D. and McVea, D. (2012), Making Sense of the Troubles: A History of the Northern Ireland Conflict. London: Penguin

Moloney, E. (2002) A Secret History of the IRA. London: Penguin Books.

Ranstorp, M. (2009) Mapping terrorism studies after 9/11: An academic field of old problems and new prospects. In: Jackson R., Smyth M., and Gunning J., (eds.) Critical Terrorism Studies. London: Routledge.pp. 13-33.

Reid, E. and Chen, H. (2007), mapping the contemporary terrorism research domain. International Journal of Human-Computer Studies. 65 42-56.

Stampnitzky, L. (2013) Disciplining Terror: How Experts Invented Terrorism. Cambridge: Cambridge University Press.

Schmid, A. P. and Jongman, A. J. (2005), Political Terrorism. London: Transaction. 
Taylor, P. (1998), Provos: The IRA and Sinn Féin. London: Bloomsbury Publishing.

Taylor, P. (2000) Loyalists. London: Bloomsbury Publishing.

Fenton, S. (2016) What is the New IRA? Why has the terror threat been raised from Northern Ireland to Great Britain? Available at: http://www.independent.co.uk/news/uk/home-news/what-is-the-new-irawhy-has-the-terror-threat-been-raised-from-northern-ireland-to-the-uk-a7024276.html

[http://www.independent.co.uk/news/uk/home-news/what-is-the-new-ira-why-has-the-terror-threat-been-raisedfrom-northern-ireland-to-the-uk-a7024276.html]_(Accessed: 27 February 2017)

The Times (1835) 'Ireland', The Times, 22 January 1835, p. 3.

The Times (1835) The Times, 12 November 1835, p. 4.

The Times (1865) 'Ireland', The Times, 19 August 1865, p. 6

The Times (1870) 'Ireland', The Times, 23 February 1870, p.12.

The Times (1880) ‘The Irish Land Agitation’, The Times, 18 October 1880 p. 9.

The Times (1880) ‘Parliament Out Of Session', The Times, 19 October 1880, p. 6.

The Times (1883) The Times, 1 November 1883, p. 10.

The Times (1885) 'Ireland', The Times, 26 January 1885, p. 9.

Todd, J. (2009) Northern Ireland: A multiphased history of conflict, a multi-levelled process of settlement. IBIS Discussion Papers: Breaking the Patterns of Conflict. Series 2, pp. 1-14.

Toolis, K. (1995) Rebel Hearts. London: Picador.

Van Krieken, R. (1999) The barbarism of civilization: cultural genocide and the stolen generations. The British Journal of Sociology. 50: 2, pp. 297-315

Van Krieken, R. (2011) Three faces of civilization: 'In the beginning all the world was Ireland'. The Sociological Review. 59 Issue Supplement (s1) pp. 24-47.

Vertigans, S. (2008) Terrorism and Societies. Aldershot: Ashgate.

Vertigans, S. (2011) The Sociology of Terrorism: People, Places and Processes. London: Routledge.

\section{Biographical note:}

Michael Dunning received his doctorate in sociology from Brunel University in 2014. His thesis focused on the sociogenesis of terrorism in Britain from the end of the eighteenth century until the present day. He has published subsequent papers on terrorism including in Historical Social Research. He has taught courses in classical sociological theory and education and social justice at the University of Leicester. He also works as a journalist.

Hosted by Michigan Publishing, a division of the University of Michigan Library.

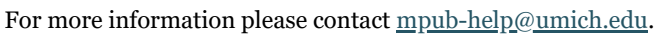

Online ISSN: 2166-6644 